\title{
Effect of Naphthalene Acetic Acid (NAA) and Gibberellic Acid (GA3) on Growth and Fruit Quality of Tomato (Lycopersicon esculentum Mill.)
}

\author{
Sanjay K. Singh ${ }^{1}$, Anil Kumar ${ }^{2}$, Karma Beer ${ }^{3 *}$, Ved P. Singh ${ }^{1}$ and Sohan K. Patel ${ }^{1}$ \\ ${ }^{1}$ Department of Horticulture, Udai Pratap Autonomous College, Varanasi, U.P., India \\ ${ }^{2}$ Department of Horticulture, SHIATS, Allahabad, U.P., India \\ ${ }^{3}$ ICAR-Indian Institute of Soil \& Water Conservation (IISWC), Koraput, Odisha, India \\ *Corresponding author
}

\section{A B S T R A C T}

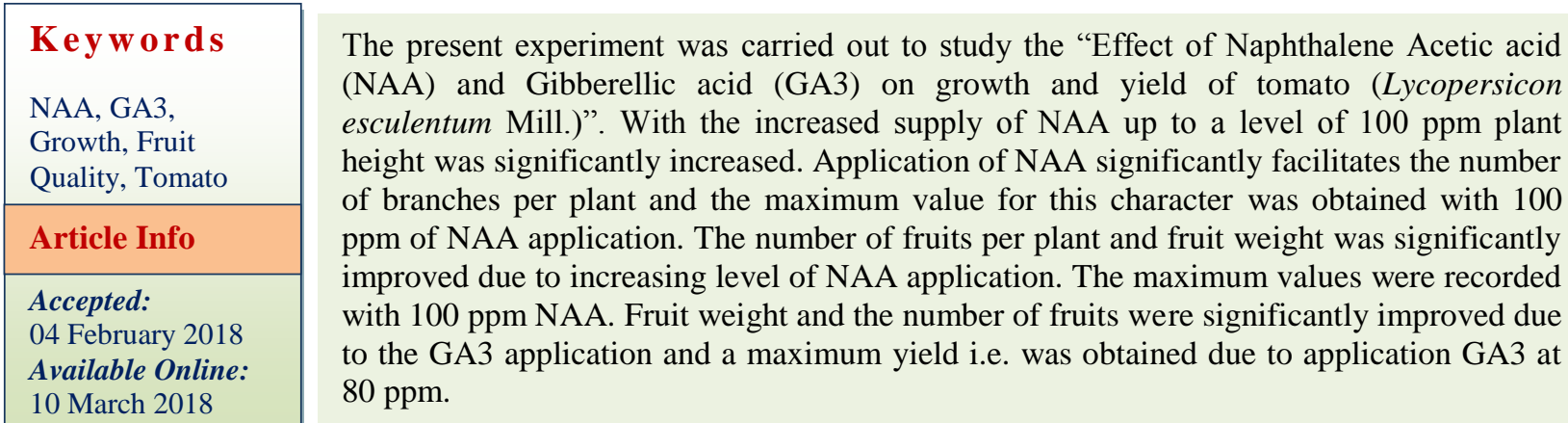

\section{Introduction}

The vegetable is the most important component of a balanced human diet and acts as a protective food. India has occupied a prime position in the world in the vegetable production and second largest producer of vegetable next to China. According to dieticians, an adult individual requires $300 \mathrm{~g}$ vegetables per days out of which $125 \mathrm{~g}$ leafy vegetable $100 \mathrm{~g}$ root and tuber vegetable and $75 \mathrm{~g}$ other vegetables for maintaining proper health. However, the per capita consumption of vegetable in India only $175 \mathrm{~g}$ which is very low as compared to the recommended dose. Production of adequate quantities of vegetable can contribute a lot in solving the food problem of our country by reducing the level of malnutrition, thus providing nutritional security. Among the vegetables, tomato (Lycopersicon esculentom Mill.) $(2 \mathrm{n}=24)$ is one of the most popular and widely grown vegetables in the world ranking second after potato.

According to Aykroyd (1963) tomato fruit contains $93.1 \mathrm{~g}$ water protein $1.99 \mathrm{~g}$, fat $0.1 \mathrm{~g}$, Carbohydrate $3.69 \mathrm{~g}$, mineral matter $0.6 \mathrm{~g}$ calcium 20mg, phosphorus $36 \mathrm{mg}$ iron $0.8 \mathrm{mg}$, carotene as (Vitamin-A) 320 IU (International Unit), thiamine $2.27 \mathrm{mg}$, iron $0.8 \mathrm{mg}$ and ascorbic acid $31 \mathrm{mg}$ per $100 \mathrm{gm}$. It also 
contains folic acid, pantothenic acid; biotin, Vitamin-K and inhibitors which are related to Vitamin-E. There are many methods adopted to increase the yield of the crop which comprises mainly of cultural and chemical practices. Application of plant growth regulators for improving the yield and quality of many vegetable crops has been emphasized by several workers. However, the improvement in yield and quality of the crop mainly depends on the concentration of plant growth regulators, method and time of application. Presently a large number of growth regulators are available in the market but basically they are two types and these are growth promoter and growth inhibitor or retardant group, though their action is quite opposite yet both the groups have profound effect on growth, yield and quality of vegetable crops. In the present study we are concerned with chemical i.e. growth regulators NAA and GA3. NAA is commonly used in horticultural crops. It also affects the physiological process, hasten maturity and produces better quality fruits and some other aspects such as to increase the number of branches, increased fresh weight, and yield (Revanappa 1998). $\mathrm{GA}_{3}$ is also one of the most important growth stimulating substances used in agriculture since long ago. It may promote cell elongation and cell division thus helps in the growth and development of many plant species. Gibberellins affect shoot elongation initiation of flower, stigma position, and fruit set, breaking dormancy, fruit size and seed number in the fruit. Keeping these facts in view the present investigation was carried out to study the Effect of Naphthalene Acetic acid (NAA) and Gibberellic acid $\left(\mathrm{GA}_{3}\right)$ on growth and fruit quality of tomato.

\section{Materials and Methods}

The present experiment was conducted at Research Farm of Indian Institute of
Vegetable Research, Varanasi which falls under the suitable niche of the vegetable dominated area of Uttar Pradesh. It is situated at 82.520 longitudes and 21.150 latitudes. To ascertain the nutritional status the experimental soil was analyzed on the basis of the soil test. The experiment was laid out in Randomized Block Design with three replications. The whole field was first divided into three main blocks and each block representing a replication. Further, each block was divided into 9 equal plots, each representing a treatment. The treatment was allocated to each replication randomly. The treatment comprised of four level of plant growth regulators GA3 (control, 20, 40, 60 and $80 \mathrm{ppm}$ ) and NAA (control 25, 50, 75 and 100 ppm) along with a control. H-86 (KashiVishesh) variety of tomato was selected for this trial. The seedlings were raised in the raised bed at the experimental farm of IIVR, Varanasi. Twenty-five days old seedlings were transplanted in the well prepared main field on 28-10-2011.Seedlings were transplanted at a spacing of $80 \times 55 \mathrm{~cm}$ in the afternoon and immediately after transplanting a light watering with rose can be given to avoid transplanting shock.

\section{Statistical analysis}

The data recorded during the study were statistically analyzed by the method as advocated by Panse and Sukhatme (1985).

\section{Results and Discussion}

In the present experiment the significant effect of $\mathrm{GA}_{3}$ and NAA on plant height, the number of branches was recorded. From the Table 1 it is clear that plant height $(\mathrm{cm})$ were found maximum in 15 DAT (38.10), 30 DAT (50.00), 45 DAT (58.10), 60 DAT (85.30) in treatment $\mathrm{T}_{5}: \mathrm{GA}_{3}(80 \mathrm{ppm})$ followed by 37.20 , $46.00,57.30,82.30$ in treatment $\mathrm{T}_{9}$ : NAA (100ppm), respectively. 
Int.J.Curr.Microbiol.App.Sci (2018) 7(3): 306-311

Table.1 Effect of Naphthalene Acetic Acid (NAA) and Gibberellic Acid (GA3) on plant height $(\mathrm{cm})$ of tomato

\begin{tabular}{|c|c|c|c|c|}
\hline Treatments & $15 \mathrm{DAT}$ & 30DAT & 45DAT & 60DAT \\
\hline $\mathrm{T}_{1}$ : Control & 17.80 & 23.40 & 29.40 & 56.20 \\
\hline $\mathrm{T}_{2}:$ GA3 (20ppm) & 23.20 & 31.00 & 37.20 & 62.60 \\
\hline $\mathrm{T}_{3}:$ GA3 (40ppm) & 26.40 & 34.80 & 47.60 & 65.20 \\
\hline $\mathrm{T}_{4}: \mathrm{GA3}$ (60ppm) & 34.40 & 41.80 & 50.20 & 75.80 \\
\hline T5: GA3 (80ppm) & 38.10 & 50.00 & 58.10 & 85.30 \\
\hline T6: NAA (25ppm) $_{6}$ & 21.20 & 28.60 & 37.20 & 60.20 \\
\hline T $_{7}:$ NAA (50ppm) & 25.80 & 30.40 & 47.80 & 64.60 \\
\hline $\mathrm{T}_{8}:$ NAA (75ppm) & 32.60 & 43.80 & 54.30 & 74.10 \\
\hline T9: NAA (100ppm) & 37.20 & 46.00 & 57.30 & 82.30 \\
\hline $\mathrm{CD}$ at $5 \%$ & 5.67 & 7.21 & 5.68 & 8.12 \\
\hline
\end{tabular}

Table.2 Effect of Naphthalene Acetic Acid (NAA) and Gibberellic Acid (GA3) on number of branches of tomato

\begin{tabular}{|c|c|c|c|}
\hline TREATMENTS & 30DAT & 45DAT & 60DAT \\
\hline $\mathrm{T}_{1}:$ Control & 1.30 & 2.40 & 4.70 \\
\hline $\mathrm{T}_{2}: \mathrm{GA3}$ (20ppm) & 1.60 & 3.00 & 5.20 \\
\hline $\mathrm{T}_{3}:$ GA3 (40ppm) & 2.00 & 3.70 & 6.70 \\
\hline $\mathrm{T}_{4}: \mathrm{GA3}$ (60ppm) & 2.80 & 4.20 & 7.40 \\
\hline $\mathrm{T}_{5}: \mathrm{GA3}$ (80ppm) & 3.70 & 4.80 & 8.00 \\
\hline T6: NAA (25ppm) & 1.40 & 2.50 & 5.00 \\
\hline T7: NAA (50ppm) & 1.97 & 3.40 & 6.30 \\
\hline $\mathrm{T}_{8}: \mathrm{NAA}$ (75ppm) & 2.68 & 4.01 & 7.10 \\
\hline T9: NAA (100ppm) & 3.30 & 4.65 & 7.70 \\
\hline CD at $5 \%$ & 1.16 & 0.41 & 2.13 \\
\hline
\end{tabular}

\section{Table.3 Effect of Naphthalene Acetic Acid (NAA) and Gibberellic Acid (GA $\left.{ }_{3}\right)$ on yield} parameters of tomato

\begin{tabular}{|l|c|c|c|c|c|}
\hline Treatments & $\begin{array}{c}\text { Number of } \\
\text { fruits per plant }\end{array}$ & $\begin{array}{c}\text { Average fruit } \\
\text { weight }(\mathrm{g})\end{array}$ & $\begin{array}{c}\text { Average Yield } \\
\text { per plant }(\mathrm{g})\end{array}$ & $\begin{array}{c}\text { Yield per } \\
\text { plot }(\mathrm{g})\end{array}$ & $\begin{array}{c}\text { Yield per } \\
\text { ha (t/ha) }\end{array}$ \\
\hline $\mathrm{T}_{\mathbf{1}}$ : Control & 13.20 & 60.50 & 0.80 & 33.54 & 38.07 \\
\hline $\mathrm{T}_{2}$ : GA3 (20ppm) & 18.70 & 64.10 & 1.20 & 50.34 & 39.62 \\
\hline $\mathrm{T}_{3}$ : GA3 (40ppm) & 22.70 & 72.15 & 1.64 & 68.79 & 41.86 \\
\hline $\mathrm{T}_{4}$ : GA3 (60ppm) & 26.20 & 75.42 & 1.98 & 82.99 & 44.65 \\
\hline $\mathrm{T}_{5}$ : GA3 (80ppm) & 30.20 & 79.25 & 2.39 & 100.52 & 48.36 \\
\hline $\mathrm{T}_{6}$ : NAA (25ppm) & 18.50 & 53.22 & 0.98 & 41.35 & 39.05 \\
\hline $\mathrm{T}_{7}$ : NAA (50ppm) & 21.70 & 62.58 & 1.36 & 57.04 & 40.27 \\
\hline $\mathrm{T}_{8}$ : NAA (75ppm) & 23.40 & 65.78 & 1.54 & 64.65 & 43.36 \\
\hline $\mathrm{T}_{9}$ : NAA (100ppm) & 24.70 & 71.14 & 1.76 & 73.80 & 47.42 \\
\hline CD at 5\% & 9.50 & 6.48 & 8.67 & 7.14 & 12.6 \\
\hline
\end{tabular}



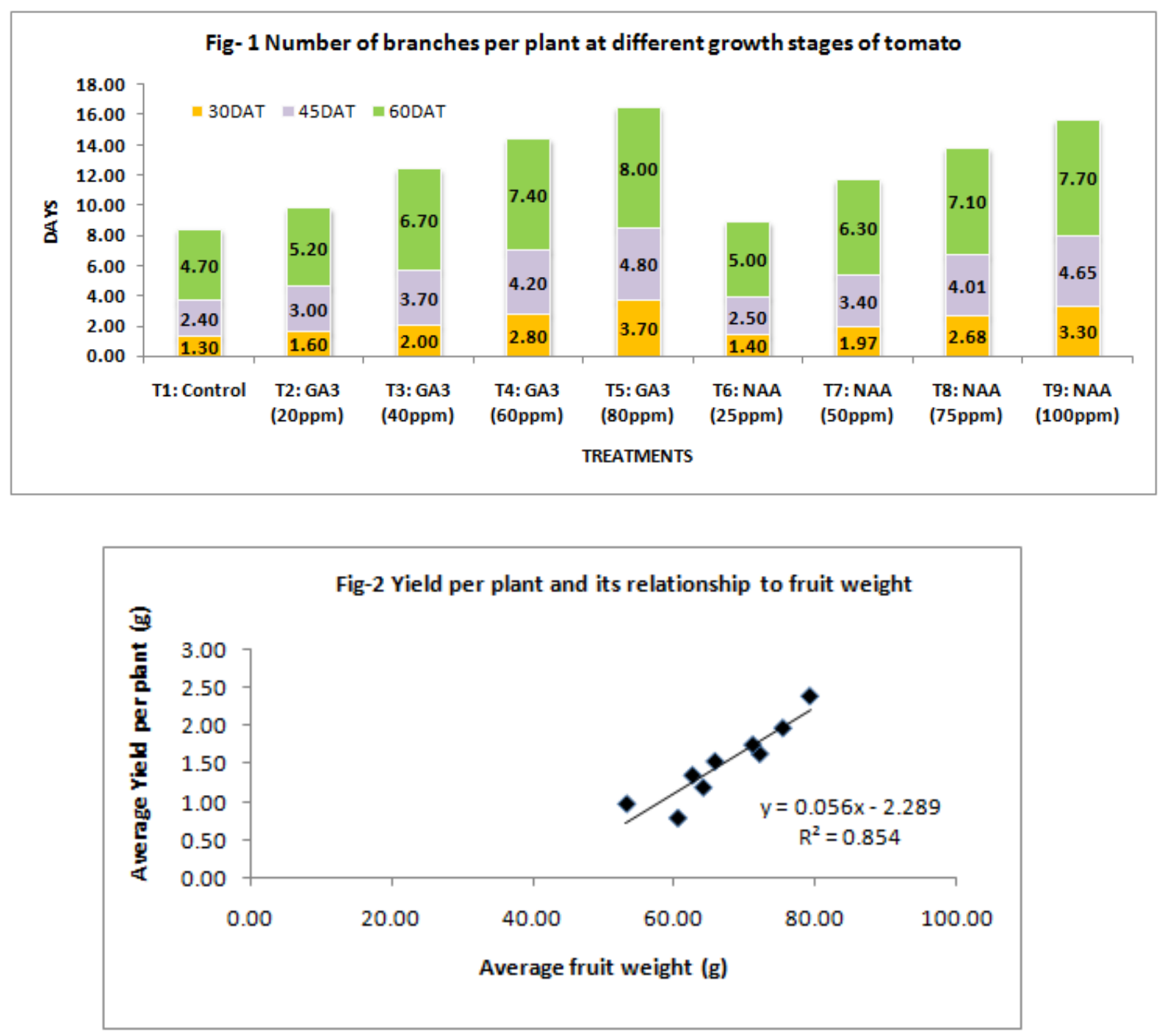

This might be due to the rapid increase in cell division and cell elongation in the meristematic region. Plant height and number of branches/plant was increased with the increasing level of GA3 and NAA. These findings are in accordance with the work reported by Revnappa (1998) and Gupta and Gupta (2000); Naeem et al., (2004), Rai et al., (2006) and Balaguera-Lopez (2009). Table 2 and Figure 1 clearly revealed that maximum number of branches were recorded 30 DAT (3.70), 45 DAT (4.80), 60 DAT (8.00) in $\mathrm{T}_{5}$ : GA3 $(80 \mathrm{ppm})$ treated plant followed by 3.30 , 4.65, 7.70 in T9: NAA (100ppm) treated tomato plant respectively. These findings are in accordance with the work reported by
Gupta and Gupta (2000) and Naeem et al., (2004). Tomato is a day-neutral crop but requires more sunny days for its flowering and fruiting. Several factors affect growth and yield of the crop. Besides genetic and environmental interaction nutrition and agronomic practices also play a significant role in yield maximization nowadays, sustainable agricultural scenario, an interaction of plant nutrient system in the form of organic, inorganic and biological components create attention. Use of GA3 and NAA in tomato is well established.

From the Table 3 it is quite clear that number of fruit per plant (30.20), average fruit weight 
$(79.25 \mathrm{~g})$, yield per plant $(2.39 \mathrm{~kg})$, yield per plot (100.52 g) and yield per ha (48.36 t) were recorded maximum in treatment $\mathrm{T}_{5}: \mathrm{GA}_{3}$ (80ppm) followed by 26.20, 75.42, 1.98, 82.99 and 44.65 respectively in $\mathrm{T}_{4}: \mathrm{GA}_{3}$ (60ppm) treated plant. Critical analysis of data presented in the present study revealed the fact that GA3 and NAA on different parameters have a significant effect on tomato as discussed hereunder. Plant growth regulator like GA3 and NAA has shown the promising result in respect of growth and yield of the crop. The response of PGR varies with the species of plant, type of chemical and its concentration. These plant growth regulators induce various physiological impacts. Application of GA3 and NAA significantly increased the number of fruits/plant. The increasing number of fruits per plant by GA3 and NAA treatments might be due to the rapid and better nutrient translocation from roots to apical parts of the plant. The increase in concentration resulted in increasing number of fruits per plant. These results are in accordance with Mozarkar et al., 1991, Bhosle et al., 2002, Pandita et al., 1999, and Singh et al., 2011. Size and weight of fruit is also an important aspect as these fruit characters are useful for yield as well as consumer acceptability. The average fruit weight, length of fruit and width of fruit were significantly increased by plant growth regulators like GA3 and NAA. It is due to the application of NAA and GA3 which causes stimulation of fruit growth that resulted in increased fruit weight, fruit length, and fruit width. Similar results have been reported by Rodrigues et al., 2001, Das and Pattanaik (1971), Lodhi et al., 2002 and Ayub et al., 2010.

\section{Relationship between yield-fruit weight per plant}

A linear relationship between yield-fruit weight per plant of tomato was observed.
Data from Figure 2 clearly revealed that when fruit weight per plant increases the yield per plant increases linearly. The regression equation (1) obtained from Figure 2 showed that; about $85.4 \%$ variation in fruit yield can be explained by fruit weight per plant. The equation also states that, per plant decrease in fruit weight the yield also reduced.

The regression equation:

$\mathrm{y}=0.056 \mathrm{x}-2.289, \mathrm{R}^{2}=0.854, \mathrm{n}=9, \mathrm{p}<0.05$

To have optimum growth of tomato CV Kashi Vishesh for getting higher and quality yield application of GA3 @ of 80ppm and NAA @ of 100ppm is useful.

\section{References}

Aykroyd, W.R. 1963. Regarding medicinal value of tomato. ICMR Special Series No. 42 quoted in vegetable crops in India by T.K. Bose and M.G. Som (1985): 249.

Ayub, R.A. and Rezende, B.L.A. (2010). Gibberellic acid contribution to tomato fruit size. Biotemas, 23:4, 25-28.

Balagura-Lopez, H.E., Cardenas Hernandez, J.F. (2009). Effect of gibberellic acid (GA3) on seed germination and growth of tomato (Solanum lycopersicum L.) Acta Hort., 821:141-147.

Bhosle, A.B., Khrbhade, SB., Sanap, P.B. and Gorad, M.J.C. (2002). Effect of growth hormones on growth, the yield of the summer tomato. (Lycopersicon esculentum Mill.). Orissa J. of Hort., 30(2): 63-65.

Das, R.C., and Pattanaik, A. (1971).Studies of the effect of growth regulators treated okra seeds (Abelmoschus esculentus L. Moench) with respect to growth and subsequent development. Indian $\mathbf{J}$. Hort., 28 (4): 293-295. 
Gupta, P.K., and Gupta, A.K. (2000). Efficacy of plant growth regulators (IAA and NAA) and micronutrient mixtures on growth, flowering, fruiting and shelf life of tomato (Lycopersicon esculentum Mill.). Bioved. 11(1/2): 2529.

Lodhi, S.K., Rathore, S.V.S., Verma, M.S., Rama P. and Prakash, S. (2002) Effect of Gibberellic acid (GA3) on the performance of chilies (Capsicum furtescens). Progressive Agriculture, 2(1): 82-83

Mozarkar, D.R., Paradkar, V.K.., Upadhyay, P.C. and Sharma, T.R. (1991). Effect of seed treatment with growth regulators on tomato varieties. Orissa J. of Hort. 19(1-2): 27-29.

Naeem, Nisar, M.F. (2001). Effect of growth regulator on tomato. Indian society of Vegetable Sci., 37(6):45-46.

Pandita, M.L.; Aroma, S.K., and Singh, K. (1999). Effect of plant growth regulators on the chemical composition of tomato (Lycopersicon esculentum
Mill.). Haryana J. of Horticultural Sci., SQA): 65-72.

Panse, V.G. and Sukhatme, P.V. Statistical Methods for Agricultural Workers, 4th ed., ICAR, New Delhi, 347 p (1985).

Rai, S., Hossain, M. and Hossain, F. (1988). Effect of growth regulators on yield and quality of okra (Abelmoschus esculentus L. Moench). Hort. Journal, 11(1):77-82.

Revanappa Natawadi, U.G. (1998). Influence of NAA and cytokinin on growth and yield of chili. Karnataka J. of Agri. Sciences, 11(4): 1136-1139.

Rodrigues, M.J., Warade, S.D. and Patil, S.D. (2001). Effect of growth regulators and truss sequence on hybrid seed yield of tomato hybrid. Advances in Plant Sciences, 4(2): 495-499.

Singh, B.K., Kumar, V., Singh, A.K. and Rai, V.K. (2011). Role of NAA on growth, yield, and quality of tomato (Lycopersicon esculentum Mill.) cultivars. Environment and Ecology, 29(3): 1091-1093.

\section{How to cite this article:}

Sanjay K. Singh, Anil Kumar, Karma Beer, Ved P. Singh and Sohan K. Patel. 2018. Effect of Naphthalene Acetic Acid (NAA) and Gibberellic Acid $\left(\mathrm{GA}_{3}\right)$ on Growth and Fruit Quality of Tomato (Lycopersicon esculentum Mill.). Int.J.Curr.Microbiol.App.Sci. 7(03): 306-311. doi: https://doi.org/10.20546/ijcmas.2018.703.036 